Transportation Research Forum

A Model of Corn and Soybean Shipments on the Ohio River Author(s): Michael W. Babcock and Stephen Fuller

Source: Journal of the Transportation Research Forum, Vol. 46, No. 2 (Summer 2007), pp. 21-34

Published by: Transportation Research Forum

Stable URL: http://www.trforum.org/journal

The Transportation Research Forum, founded in 1958, is an independent, nonprofit organization of transportation professionals who conduct, use, and benefit from research. Its purpose is to provide an impartial meeting ground for carriers, shippers, government officials, consultants, university researchers, suppliers, and others seeking exchange of information and ideas related to both passenger and freight transportation. More information on the Transportation Research Forum can be found on the Web at www.trforum.org. 


\section{A Model of Corn and Soybean Shipments on the Ohio River}

This paper estimates the demand for corn and soybean shipments on the Ohio River during the 19922004 period. Using monthly data, OLS (with Newewy-West standard errors) parameters estimates were obtained for the explanatory variables. Results indicate that Ohio River corn and soybean shipments are significantly and positively affected by one month lagged shipments, corn and soybean stocks in the Ohio River production region, and corn and soybean exports from lower Mississippi River Gulf ports. Some empirical support was found for a significant negative relationship between Ohio River corn and soybean shipments and ocean shipping freight rates from lower Mississippi River Gulf ports to Japan. Indiana corn prices did not significantly affect Ohio River corn and soybean shipments.

\section{by Michael W. Babcock and Stephen Fuller}

In the past 10 years, researchers have extensively studied grain transportation on the inland waterways. Some studies have investigated the determinants of grain barge demand such as grain exports, barge prices, railroad grain transport prices, U.S. grain demand and supply, and weather. Other studies have focused on measuring the benefits of extending 600-foot locks to 1,200 feet (i.e., reduction of lock delays and associated barge costs) relative to the costs of these navigation improvements. To measure the benefits, these studies have often made long-term (i.e., 25-year) forecasts of grain traffic on the inland waterways. Several studies in the past few years have measured short-run and long-run price elasticities of demand for barge grain transport. Nearly all of these studies have empirically implemented their models for the Upper Mississippi River and Illinois Waterway since these are the main grain carrying rivers. Thus there is a need to extend the study of grain transportation demand to other grain carrying waterways, and compare the results to those of previous studies. The objective of this paper is to partially fill this research gap by estimating the demand for corn and soybean barge shipments on the Ohio River.

The Ohio River extends 981 miles from Pittsburg, Pennsylvania, to the mouth of the river at Cairo, Illinois. Coal is the primary commodity shipped on the Ohio River, accounting for about $50 \%$ of the total tonnage (U.S. Army Corps of Engineers 2005). Large amounts of crude oil and petroleum products as well as stone and ores also move on the Ohio River. In 2003, nearly 12 million tons of grain and oilseeds were shipped on the Ohio River, nearly all of which was corn and soybeans (U.S. Army Corps of Engineers 2005). Almost all of this grain flows into the Mississippi River and is exported from Mississippi River Gulf ports. In 2000, 67.7 million tons of grain and oilseeds were exported by barge through all U.S. ports (U.S. Department of Agriculture 2004). Shipments of grain and oilseeds on the Ohio River in year 2000 were 12.9 million tons or about 19\% of total U.S. exports by barge (U.S. Army Corps of Engineers 2002).

A review of the literature revealed several studies of grain freight demand on the inland waterways. Babcock and German (1983) estimated the price elasticity of demand for grain transportation on U.S. inland waterways to be -0.64. Harnish and Dunn (1998) estimated a reduced form model of the determinants of grain barge rates on the Mississippi River system. They found that grain exports, coal barge rates, input costs, and distance influence grain barge rates. Miljkovic, Price, Hauser, and Algozin (2000) estimated a structural model of export-bound grain movement on the Illinois Corridor that included both the rail and barge modes. The estimated equations associated with the rail and barge markets linking Illinois to lower Mississippi River ports were price dependent equations. Therefore, the own-price elasticities could not be obtained. They estimated that a $1 \%$ increase in the supply of barge service would reduce barge rates between $-0.49 \%$ and $-0.54 \%$. They 


\section{A Model of Corn and Soybean Shipments}

also discovered that barges and railroads are partial substitutes in the export grain market, and that grain exports did not have a statistically significant effect on the demand for either the barge or rail modes.

A group of studies has evaluated the benefits and costs of making navigation improvements in the waterway system. Jack Faucett Associates (1997) forecast waterway traffic (mainly grain) on the Upper Mississippi River/Illinois Waterway. In Jack Faucett Associates (2000), the 1997 grain forecasts were dropped and new grain forecasts were presented. However, Bitzan and Tolliver (2000) concluded that the revised Jack Faucett Associates forecasts of U.S. grain exports failed to adequately consider foreign grain supply and demand, and that many of the components of the forecast were not transparent.

Fellin, Fuller, Grant, and Smotek (2001) estimated quadratic programming models to estimate benefits of inland waterway improvements. Using much debated U.S. Army Corps of Engineers estimates of projected traffic for year 2020 and the associated lock delays and barge costs, grain producers' revenues decline by about $\$ 364$ million per year if no improvements are made to the locks on the Upper Mississippi River and Illinois Waterway. However, they found that extending the lock chambers at locks 20-25 on the Upper Mississippi River, and the Peoria and LaGrange locks on the Illinois Waterway, would increase grain producers’ revenues by $\$ 93.57$ million per year. The authors did not estimate the costs of these investments.

Gervais, Misawa, McVey, and Baumel (2001) used a highly disaggregated linear programming model to evaluate the short run benefits of extending five 600-foot locks on the Upper Mississippi River (UMR) to 1,200 feet. They simulate two scenarios based on either complete or partial passthrough to grain elevators and producers of the cost savings associated with the lock extensions on the UMR. They estimate the total annual cost of the lock expansions at four cents per bushel, whereas the total annual benefits accruing to grain producers and elevators are only $\$ 0.21$ to $\$ 0.43$ cents per bushel.

Some recent studies have focused on estimating own-price elasticity of demand for barge service. Yu and Fuller (2005) estimated an own-price elasticity of demand of -0.48 , and found that barge rates, foreign grain demand, rail rates, winter season, and floods influenced grain barge demand on the Upper Mississippi River. Dager, Bray, Murphee, and Leibrock (2004) found that own-price elasticity of demand for barge service ranged from -0.42 to -0.72 for various segments of the Upper Mississippi River and Illinois Waterway. Boyer and Wilson (2005) examined the effect of barge rates on Mississippi River corn shipments and estimated the own-price elasticity of demand to range from -0.02 to -0.35 . Yu, Zhang, and Fuller (2006) estimated structural demand models for barge grain transport on the Upper Mississippi and Illinois Rivers. They found that the short run own-price elasticity of demand is -0.43 and the long run elasticity is -0.80 for the Upper Mississippi River. The corresponding elasticities for the Illinois Waterway were estimated to be -0.21 and 0.31. In contrast to other studies, Hendrickson and Wilson (2005) concluded own-price elasticity of demand to be in the elastic range from -1.3 to -1.9 .

Sitchinava, Wilson, and Burton (2007) used a stated preference approach to develop barge demand estimates for a wide range of heterogenous demanders. The data are generated from a survey of Ohio River Valley shippers. The authors found that the barge rate elasticities varied from -0.10 to -0.44 for coal, from -0.17 to -1.02 for manufacturers, and from -0.36 to -2.79 for the other group of commodities. They also discovered that barge shippers are more responsive to rates than transit time.

\section{THEORY OF TRANSPORT DEMAND}

The demand for grain barge transportation service that links the Ohio River Valley grain production region (Indiana, Ohio, and Kentucky) with lower Mississippi River ports is a derived demand. Therefore, factors that shift grain supply and demand in the production region and export demand, as reflected at lower Mississippi River ports, will define and shift the demand for barge transportation 
(Boyer 1997). A two-region spatial equilibrium model is used to illustrate the theoretical foundation of grain barge demand (Figure 1).

Figure 1: Two-Region Spatial Equilibrium Model and Derived Transportation Market

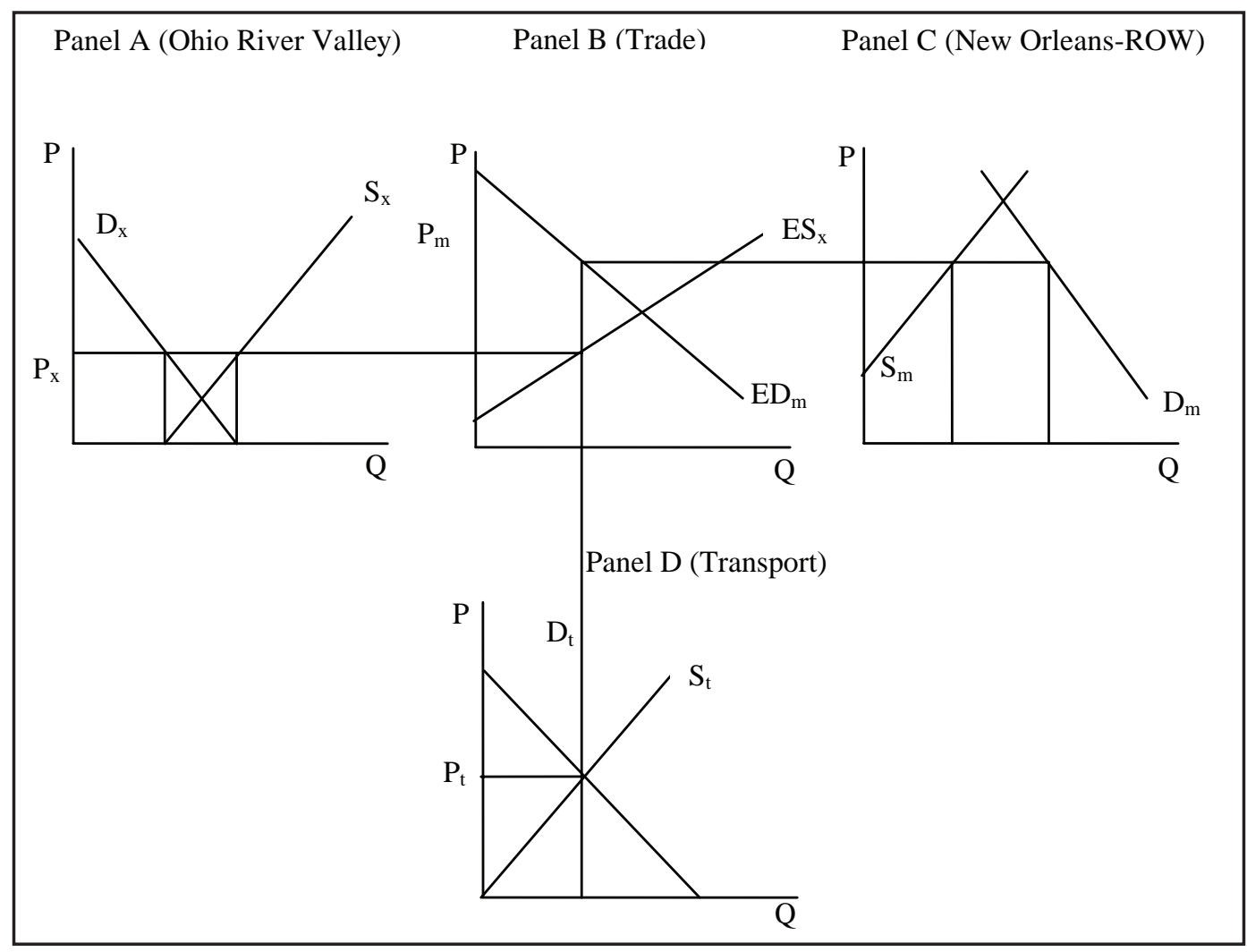

Panel A depicts the supply $\left(\mathrm{S}_{\mathrm{x}}\right)$ and demand $\left(\mathrm{D}_{\mathrm{x}}\right)$ of grain in the Ohio River Valley while Panel $\mathrm{C}$ represents the rest of the world's (ROW) demand and supply for grain as reflected at lower Mississippi River ports. Panel B is the trade panel which includes the excess grain supply of the Ohio River Valley grain production region $\left(\mathrm{ES}_{\mathrm{x}}=\mathrm{S}_{\mathrm{x}}-\mathrm{D}_{\mathrm{x}}\right.$ ), and the excess demand of the foreign countries that purchase grain at lower Mississippi River ports $\left(\mathrm{ED}_{\mathrm{m}}=\mathrm{D}_{\mathrm{m}}-\mathrm{S}_{\mathrm{m}}\right)$. The intersection of excess supply $\left(\mathrm{ES}_{\mathrm{x}}\right)$ and excess demand $\left(\mathrm{ED}_{\mathrm{m}}\right)$ determines the equilibrium price and quantity of grain traded between the Ohio River Valley grain production region and lower Mississippi River ports if no transportation costs were required to link the two regions. Of course, transportation costs are very important in the marketing of grain. The derived demand for grain transportation and the supply of grain transportation service are depicted in Panel D. The derived transportation demand is equal to the vertical distance between the excess supply $\left(\mathrm{ES}_{\mathrm{x}}\right)$ and excess demand $\left(\mathrm{ED}_{\mathrm{m}}\right)$ in Panel B. Also in Panel D is the supply of transportation service linking the Ohio River Valley grain production region to lower Mississippi River ports. Since barges transport nearly all of the grain from the production region to lower Mississippi River ports, it is reasonable to assume that the supply is an approximation of the grain barge fleet operating on the Ohio River. The intersection of the derived transport demand and barge supply determines the transportation rate $\left(\mathrm{P}_{\mathrm{t}}\right)$ linking Indiana, Ohio, and Kentucky to lower Mississippi River ports. The corresponding grain prices are $\mathrm{P}_{\mathrm{x}}$ in Panel A for the grain production region and $\mathrm{P}_{\mathrm{m}}$ in Panel $\mathrm{B}$ for the port area, where grain prices in the two regions $\left(\mathrm{P}_{\mathrm{x}}\right.$ and $\left.\mathrm{P}_{\mathrm{m}}\right)$ differ by the barge transport rate $\left(\mathrm{P}_{\mathrm{t}}\right)$ that links the two regions.

Any variable that shifts the regional supply $\left(\mathrm{S}_{\mathrm{x}}\right)$ and demand $\left(\mathrm{D}_{\mathrm{x}}\right)$ of grain in the Ohio River Valley will shift the excess supply $\left(\mathrm{ES}_{\mathrm{x}}\right)$ and the derived transport demand. Similarly, any 
variable that shifts the ROW excess grain demand and supply will alter the derived demand for barge transportation. Therefore, these "shifter" variables must be included in the specification and estimation of the demand for grain barge transportation.

In addition to the economic forces identified in the partial equilibrium case in Figure 1, other transport modes compete with as well as complement grain barge transportation. For example, all grain moved by barge must be delivered to river ports by truck or rail (likely shortline railroads) resulting in a complementary relationship. Alternatively, grain shippers in Indiana, Ohio, and Kentucky may wish to ship grain to alternative markets which are only served by railroads, such as the livestock and poultry feeding markets in the southeastern U.S., resulting in a rail vs. barge competitive relationship. Ocean shipping rates linking lower Mississippi River ports to Asia may have a complementary relationship with grain barge demand on the Ohio River.

\section{MODEL SPECIFICATION}

The general form of the model is as follows:

$$
q_{b, t}=f\left(q_{b, t-1}, p_{b, t}, e_{g, t}, \text { domd }_{g, t}, \text { doms }_{g, t}, p_{o, t}\right)
$$

$\mathrm{q}_{\mathrm{b}, \mathrm{t}}$ - quantity of grain barge service purchased by river grain shippers per unit of time $\mathrm{t}$

$\mathrm{p}_{\mathrm{b}, \mathrm{t}}-$ grain barge rate

$\mathrm{ex}_{\mathrm{g}, \mathrm{t}}$ - grain exports

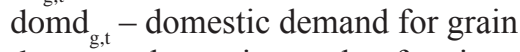

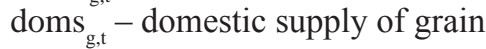

$\mathrm{p}_{\mathrm{o}, \mathrm{t}}-$ proxy variable for transportation rates of other modes

Grain barge transportation on the Ohio River is characterized by significant seasonality (Figure 2). Thus, the quantity of grain moved by barge in previous time periods may influence current period barge demand. Thus, lag(s) of the dependent variable are included in the demand equation as an explanatory variable. With this addition, the demand equation becomes a partial adjustment model: a special case of the autoregressive distributed lag (ADL) model (Davidson and Mackinnon 1993).

The law of demand predicts an inverse relationship between the dependent variable and barge rate. Demand for U.S. grain in foreign countries has an impact on Ohio River barge shipments. An increase in foreign grain demand is expected to shift grain barge demand to the right. Thus, a positive relationship is expected between foreign grain demand and the derived demand for grain barge transport. The supply of and demand for grain in the Ohio River Valley grain production region is expected to influence grain barge demand on the Ohio River. Regional grain supply is expected to have a positive relationship to derived grain barge demand since an increase in grain supply ( $\mathrm{S}_{\mathrm{x}}$ in Panel A, Figure 1) will shift the excess supply curve (Panel B) and the derived barge demand curve to the right. In contrast, an increase in domestic grain demand is expected to have a negative effect on grain barge transport demand due to the leftward shift of the excess grain supply curve and the derived barge transport demand.

Prices of other transportation modes may influence grain barge demand on the Ohio River. Railroad grain rates to markets not served by the Ohio River would have an expected positive relationship to grain barge demand. If rail rates increase, the non-water served rail markets become less attractive, causing grain shippers to divert from rail to water carriers. If the rate of a complementary mode (rail or truck) increases, the quantity of grain shipped to the river would be expected to decrease. Accordingly, the demand for grain barge transport would decrease or shift to the left. Ocean freight rates may also impact grain barge demand on the Ohio River. A relatively high ocean freight rate linking lower Mississippi River ports to importing countries would be expected to negatively affect the demand for U.S. grain and grain barge demand on the Ohio River. 


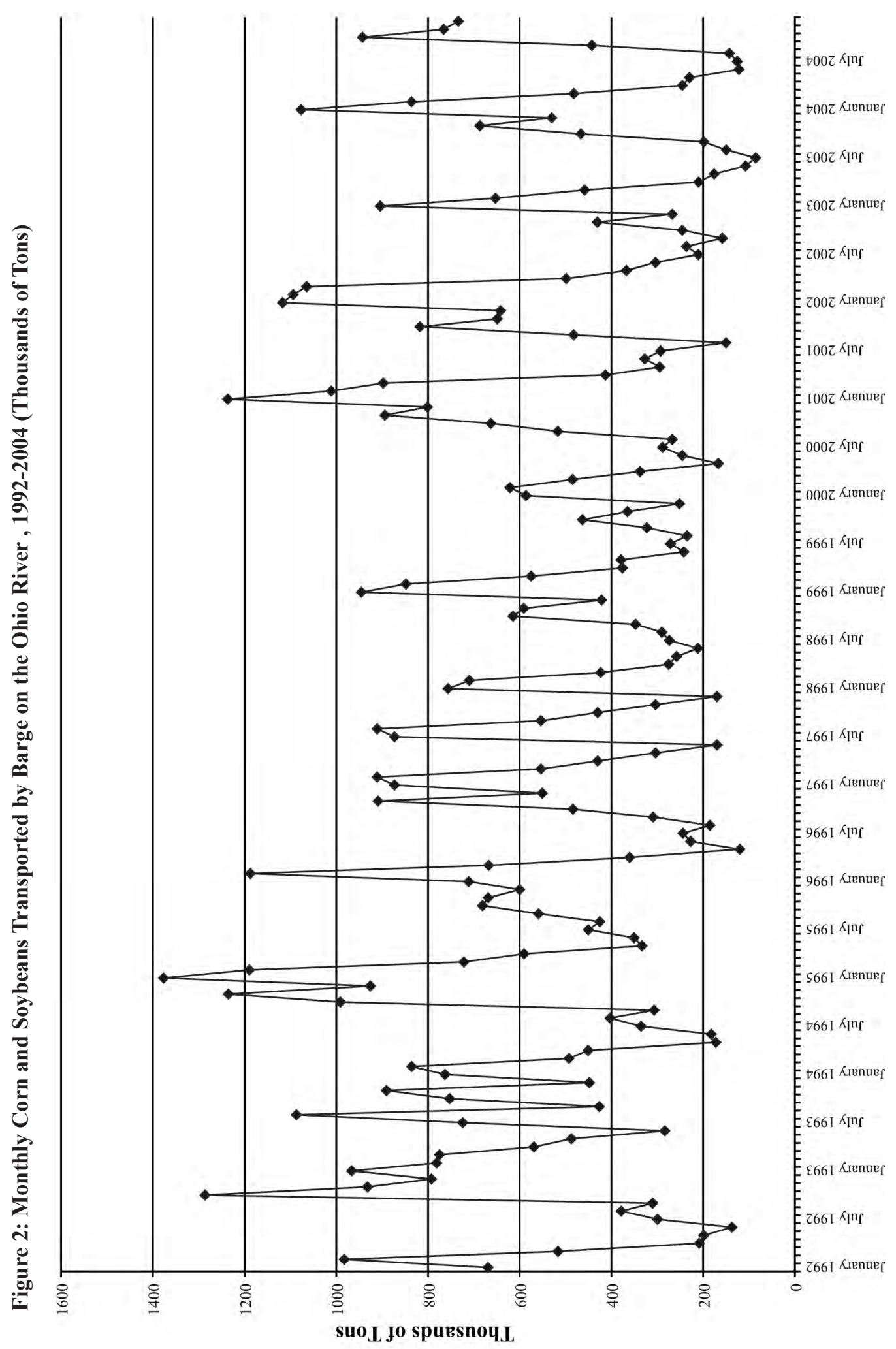


A Model of Corn and Soybean Shipments

\section{VARIABLES AND DATA}

Table 1 contains the definitions of all continuous variables in the estimated Ohio River grain barge demand equation, and the descriptive statistics are displayed in Table 2.

Table 1: Definitions of Grain Barge Demand Variables for the Ohio River

\begin{tabular}{ll} 
Variable & Definition \\
\hline ORSHIP $_{\mathrm{i}}$ & Corn and Soybean Barge Shipments on the Ohio River in month i (tons) \\
ORRATES $_{\mathrm{i}}$ & Lower Ohio River Grain Barge Rates in month i (percent of tariff) \\
CBSTOCK $_{\mathrm{i}}$ & $\begin{array}{l}\text { Corn and Soybean Stocks in the states of Indiana, Ohio, and Kentucky in } \\
\text { month i (thousands of bushels) }\end{array}$ \\
EXPORT $_{\mathrm{i}}$ & $\begin{array}{l}\text { Corn and Soybean Inspections for Export at Lower Mississippi River Gulf } \\
\text { Ports in month i (thousands of short tons) }\end{array}$ \\
INCP $_{\mathrm{i}}$ & $\begin{array}{l}\text { Average Indiana Corn Price in month i (dollars per short ton) } \\
\text { ORJP }_{\mathrm{i}}\end{array}$ \\
\hline $\begin{array}{l}1_{2} \text { a short ton is 2,000 pounds } \\
\text { a metric ton is about 2,200 pounds }\end{array}$
\end{tabular}

The following variables were included in the Ohio River grain barge demand equation: (1) corn plus soybean barge shipments per month on the Ohio River (ORSHIP ${ }_{\mathrm{i}}$ ), the dependent variable;

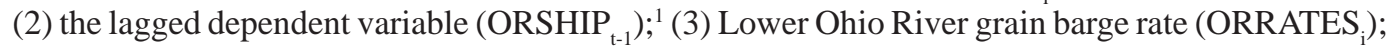
(4) export demand for corn and soybeans at lower Mississippi River ports (EXPORT); (5) average Indiana corn price (INCP ${ }_{i}$ ), which is a measure of domestic grain demand; (6) corn plus soybean stocks in the states of Indiana, Ohio, and Kentucky (CBSTOCK $)_{\mathrm{i}}$ which represents grain supply in the Ohio River Valley grain production region; and (7) ocean freight rates from lower Mississippi River Gulf ports to Japan (ORJP), a proxy for the rates of complementary modes.

ORSHIP $_{\mathrm{i}}$ represents the quantity of corn and soybeans shipped per month from the Ohio River

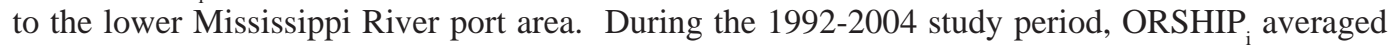
about 526,000 tons per month (Table 2). As shown in Figure 2, the peak flows occur in the first and fourth quarters of the year, with relatively lower shipments in the spring and summer seasons. Barge rates (ORRATES $_{\mathrm{i}}$ ) also exhibit strong seasonality with relatively high rates in the third and fourth quarters of the year and relatively lower rates in the second and third quarters. The mean value of the barge rate was $152 \%$ of the base tariff rate (Table 2$)^{2}$

Corn plus soybean inspections for export at lower Mississippi River Gulf ports represent foreign country grain demand. The average quantity inspected for exports per month was about 4.6 million tons (Table 2).

Combined corn and soybean stocks in Indiana, Ohio, and Kentucky (CBSTOCK $)_{i}$ represent grain supply in the production region. Grain stocks are reported quarterly, so the quarterly values were interpolated to obtain estimated monthly values. The mean corn plus soybean stock level during the study period was about 674 million bushels per month (Table 2). 
A Model of Corn and Soybean Shipments

Table 2: Statistical Summary of Variables in the Ohio River Demand Equation

\begin{tabular}{lccccc}
\hline Variable & Unit of Measure & Mean & $\begin{array}{c}\text { Standard } \\
\text { Deviation }\end{array}$ & $\begin{array}{c}\text { Minimum } \\
\text { Value }\end{array}$ & $\begin{array}{c}\text { Maximum } \\
\text { Value }\end{array}$ \\
\hline ORSHIP & tons & 525,808 & $302,249.7$ & 85,624 & $1,376,373$ \\
ORRATES & percent of tariff & 152.09 & 57.30 & 83 & 358 \\
CBSTOCK & 1,000 of bushels & $674,417.7$ & $362,805.8$ & 50,059 & $1,559,289$ \\
EXPORT & 1,000 of short tons & $4,625.51$ & $1,085.33$ & 2,287 & 6,717 \\
INCP & $\$$ per short ton ${ }^{1}$ & 86.08 & 19.70 & 58.21 & 167.86 \\
ORJP & $\$$ per metric ton ${ }^{2}$ & 26.24 & 11.46 & 12.51 & 72.75 \\
\hline $\begin{array}{l}1 \\
2\end{array}$ a short ton is 2,000 pounds & & & &
\end{tabular}

Domestic demand for corn and soybeans in the proximity of the Ohio River was represented in the grain barge demand equation by average Indiana corn prices (INCP ${ }_{\mathrm{i}}$ ). Higher domestic corn prices suggest increased domestic corn demand, which is expected to have a negative influence on grain barge traffic on the Ohio River, almost all of which is exported. Thus, as domestic demand absorbs more of the grain supply, less is available for export. The mean corn price during the 19922004 study period was about $\$ 86$ per ton (Table 2).

The ocean grain rate linking the U.S. to Japan $\left(\mathrm{ORJP}_{\mathrm{i}}\right)$ is included in the barge demand equation to capture the impact of this complementary rate on Ohio River grain barge demand. ${ }^{3}$ The mean value of the monthly ocean grain rate was $\$ 26.24$ per metric ton (Table 2).

As noted above, it is desirable to include rates of competing modes in the grain barge demand equation. Specifically, railroad rates from the production region to markets not served by the Ohio River need to be in the equation. However, the destinations of rail shipped corn and soybeans of the production region are not known. There is some evidence of significant rail flows from Ohio and Indiana to livestock and poultry feeding locations in the southeastern U.S. (Fruin et al. 1990). However, the data in the study is over 20 years old. Even if the rail served destinations of Indiana and Ohio corn and soybean shipments were known with certainty, it would be very difficult to compile a monthly series of railroad rates to these destinations or a representative destination. Thus, rail rates are not in the equation due to data unavailability.

The data for monthly corn and soybean shipments on the Ohio River (ORSHIP ${ }_{\mathrm{i}}$ ) was obtained from personnel at the U.S. Department of Agriculture, Agricultural Marketing Service (AMS). The

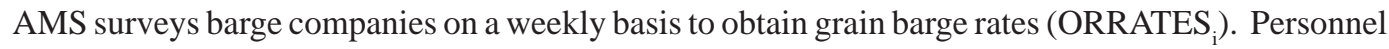
at AMS supplied this data (converted to monthly averages) for the entire study period. Agricultural Marketing Service personnel also provided data for monthly corn and soybean inspections for export at lower Mississippi River Gulf ports (EXPORT $)$, and ocean freight rates from lower Mississippi River Gulf ports to Japan (ORJP ${ }_{\mathrm{i}}$ ). Data for corn and soybean stocks of Indiana, Ohio, and Kentucky $\left(\right.$ CBSTOCK $_{\mathrm{i}}$ ) were obtained from the January release of Grain Stocks published by U.S. Department of Agriculture, National Agricultural Statistics Service (NASS). Average Indiana corn price data was obtained from Indiana Agricultural Statistics—Annual Summary, 2004-05 (U.S. Department of Agriculture 2006). 
A Model of Corn and Soybean Shipments

\section{MODEL ESTIMATION}

\section{OLS vs. 2SLS Estimates}

Theoretically, the quantity of barge shipments and barge prices are jointly determined. Thus, a simultaneity bias may occur with OLS coefficient estimates since barge price may be correlated with the demand equation residuals, resulting in biased and inconsistent parameter estimates.

Since barge rate is a potential endogenous variable, identification requires at least one instrumental variable (Baltagi 2002). The instruments must be exogenous variables that are uncorrelated with the residual term in the demand equation. The instrumental variables selected for barge rate include a one-month lagged barge rate variable, diesel price, and the wage index for transportation and public utility workers. The lagged barge rate was selected as an instrument since it would not be affected by current period barge demand. Diesel price (DIESEL) and the wage index (Wage X) were selected since they are shifters of the supply curve for Ohio River grain barge transportation, satisfying the exogeneity and relevance conditions necessary for instruments. Diesel price was obtained from the website of the U.S. Department of Energy (2007), and the wage index from U.S. Department of Labor (2007).

If instruments explain very little of the variation in endogenous variables, the weak instruments can bias the 2SLS estimator (Stock and Watson 2003). Stock and Watson (2003) offer a rule of thumb (p. 350) for identifying weak instruments. The rule is that when there is a single endogenous regressor, a first stage F-statistic less than 10 indicates weak instruments. The F-statistic for the first stage regression was 45.05 for the model in Table 3 and 37.5 for the model in Table 4 . Of the three instrumental variables, only the one-month lagged barge rate was statistically significant.

The 2SLS parameter estimates were not substantially different from the OLS estimates in Tables 3 and 4. The algebraic signs and statistical significance of the variables were nearly the same in every case. See Appendices A and B for the 2SLS empirical results.

\section{Empirical Results}

The equations for corn and soybean shipments on the Ohio River are in Tables 3 and 4 . The equations were estimated with OLS with Newey-West standard errors, which are robust to auto correlation in the error term (i.e., no serial correlation problem). The equations were estimated in monthly frequency over the 1992-2004 time frame. The partial correlation coefficient between EXPORT and CBSTOCK was relatively high. So to mitigate the effect of multicollinearity on the coefficient estimates, the demand equation was estimated without EXPORT (Table 3). Then CBSTOCK was removed from the equation and the equation was re-estimated with EXPORT included (Table 4).

In Table 3, ORSHIP ${ }_{\mathrm{t}-1}$ has the theoretically expected positive sign and is statistically significant at the .01 level. CBSTOCK has the theoretically expected positive sign and is highly significant. The ocean shipping rate from lower Mississippi River Gulf ports to Japan (ORJP) has the expected negative sign and is significant at the 0.05 level. Contrary to theoretical expectations, the sign of Indiana corn price (INCP) was positive. However, it was not statistically significant. 
Table 3: OLS Estimates of Grain Barge Demand on the Ohio River (Excluding Exports)

(1992-2004)

\begin{tabular}{lcc}
\hline Variable & Coefficient & t-statistic \\
\hline ORSHIP $_{\mathrm{t}-1}$ & 0.393 & $6.70^{* * *}$ \\
ORRATES $_{\mathrm{i}}$ & $2,033.0$ & $6.45^{* * *}$ \\
CBSTOCK $_{\mathrm{i}}$ & 0.353 & $6.01^{* * *}$ \\
ORJP $_{\mathrm{i}}$ & $-3,500.476$ & $-2.36^{* *}$ \\
INCP $_{\mathrm{i}}$ & 618.518 & 1.00 \\
Constant $^{\text {Adjusted }}$ & $-189,672.1$ & $-2.11^{* *}$ \\
\hline
\end{tabular}

* significant at the .10 level

$* *$ significant at the .05 level

*** significant at the .01 level

Table 4: OLS Estimates of Grain Barge Demand on the Ohio River (Excluding Grain Stocks) (1992-2004)

\begin{tabular}{lcc}
\hline Variable & Coefficient & t-statistic \\
\hline ORSHIP $_{\mathrm{t}-1}$ & 0.539 & $9.96^{* * *}$ \\
ORRATES $_{\mathrm{i}}$ & 949.358 & $2.71^{* * *}$ \\
EXPORT $_{\mathrm{i}}$ & 77.769 & $3.85^{* * *}$ \\
ORJP $_{\mathrm{i}}$ & $-1,422.645$ & -1.19 \\
INCP $_{\mathrm{i}}$ & -503.395 & -0.68 \\
Constant $^{\text {Adjusted R }}$ & $-181,958.4$ & -1.56 \\
\hline
\end{tabular}

** significant at the .05 level

*** significant at the .01 level

When the equation is re-estimated without CBSTOCK and including EXPORT (Table 4), ORSHIP $_{\mathrm{t}-1}$ has the theoretically expected positive sign and is statistically significant at the 0.01 level. EXPORT has the expected positive sign and is highly significant. Variables ORJP and INCP have the theoretically expected negative signs but neither is statistically significant.

Unexpectedly, the sign of barge rates (ORRATES) was positive and significant at the 0.01 level in both Table 3 and Table 4 . This result does not seem to have been caused by multicollinearity since the partial correlation coefficients of barge rate and the other explanatory variables are relatively low. As noted above, corn and soybean shipments on the Ohio River have a seasonal pattern, with relatively high shipments in the first and fourth quarter of the year and relatively low shipments in the second and third quarters. Barge rates on the lower Ohio River exhibit a similar seasonal pattern with relatively higher rates in the third and fourth quarter of the year and relatively lower rates in the 
first and second quarter. If barge supply is relatively price inelastic on the Ohio River, an increase in barge demand would result in both an increase in barge price and corn and soybean shipments. An alternative hypothesis assumes that shipments of other major Ohio River commodities such as coal, petroleum products, and ores are non-seasonal. If this is the case, the seasonal surge of corn and soybean shipments would cause barge rates to increase.

\section{CONCLUSION}

This study estimated demand for corn and soybean shipment on the Ohio River for the 19922004 period. Using monthly data, OLS (with Newey-West standard errors) parameter estimates were obtained for the explanatory variables. Results indicate that Ohio River corn and soybean shipments are significantly affected by one month lagged shipments (ORSHIP $\left.{ }_{t-1}\right)$, corn and soybean stocks in the Ohio River production region (CBSTOCK), and corn and soybean exports from lower Mississippi River Gulf ports. Some empirical support was found for the impact of ocean shipping freight rates from lower Mississippi River Gulf ports to Japan (ORJP). Indiana corn prices (INCP) did not significantly affect Ohio River corn and soybean shipments.

It is interesting to compare the results of this study to those of similar recent studies of other rivers, such as Yu, Zhang, and Fuller (2006), who investigated freight transportation demand for corn and soybeans on the Upper Mississippi and Illinois Rivers. This study and Yu et al. (2006) have similarities and differences. Both studies found that lagged shipments and exports are positively and significantly related to freight demand. However, there are also differences in the findings of the two studies. For example, corn and soybeans stocks (regional grain supply) were positive and statistically significant in this study, but were positive and non-significant in the Yu et al. (2006) study. The ocean shipping rate from lower Mississippi River Gulf ports to Japan was positive and non-significant for the Upper Mississippi River, and positive and statistically significant for the Illinois Waterway. In contrast, this study found ORJP to be negative and statistically significant in one equation (Table 3) and negative and non-significant in another equation (Table 4). This study found that regional corn prices (INCP) had a positive, but non-significant effect on Ohio River corn and soybean shipments. Regional corn prices in the Yu et al. (2006) study had a negative and nonsignificant effect on corn and soybean shipments on the Upper Mississippi River, and a negative and statistically significant impact on Illinois Waterway shipments. The largest difference in the two studies was the coefficient of the barge price variable which was negative and significant in the $\mathrm{Yu}$ et al. (2006) study and positive and significant in this study.

Freight demand analysis is a necessary antecedent of a long-term study of the future of the lock and dam system on the Ohio River. This paper suggests that a comprehensive study of future foreign grain demand is critical since exports are an important variable influencing Ohio River grain traffic. This study also found that regional grain stocks have a significant impact on Ohio River corn and soybean shipments. Thus, the future grain production in the region and how federal farm policies will affect production need to be analyzed. Study results also indicate that forecasts of ocean freight rates for U.S. grain to foreign destinations would be useful since these rates impact corn and soybean shipments on the Ohio River.

\section{Endnotes}

1. Multiple lag structures were tested including 12-month lags, but only the one-month lag was statistically significant.

2. The barge industry uses percent of tariff as rate units for buying and selling barge services. These rate units are from the Bulk Grain and Grain Products Freight Tariff No. 7 which was used by the Waterways Freight Bureau of the Interstate Commerce Commission (ICC). In 1976, the U.S. Department of Justice entered into an agreement with the ICC that made Tariff No. 7 no longer 
applicable, but the barge industry continues to use it as a benchmark. For example, Tariff No. 7 (1976) has a grain barge rate of $\$ 4.04$ per ton for the lower Ohio River. If the current rate is $200 \%$ of tariff then the rate is $\$ 8.08$ per ton $(2.0 \times \$ 4.04=\$ 8.08)$.

3. Gulf of Mexico grain exports represent exports to all foreign countries, whereas the ocean grain rate to Japan is associated with only a portion of total Gulf grain exports. The correlation coefficient between these two variables is only 0.053 .

\section{References}

Babcock, M.W. and H.W. German. "Forecast of Water Carrier Demand to 1985." Proceedings of the Transportation Research Forum 24(1), (1983): 249-257.

Baltagi, B.H. Econometrics. 3rd ed. Springer, Berlin, 2002.

Bitzan, J.D. and D.D. Tolliver. Review of Waterway Grain Traffic Forecasts for the Upper Mississippi River Basin. Submitted to the U.S. Army Corps of Engineers, New Orleans District. http://www. mvr.usace.army mil/pdw/nav_study/JFAreport.pdf, 2000.

Boyer, K.D. Principles of Transportation Economics. Addison-Wesley, Reading, Massachusetts, 1997.

Boyer, K.D. and W. Wilson. Estimation of Demands at the Pool Level. U.S. Army Corps of Engineers, Institute of Water Resources. http://www.corpsnets.us/inlandnav.cfm, 2005.

Dager, C., L. Bray, C. Murphree, and C. Leibrock. Elasticity of Demand for Barged Grain Shipments on the Upper Mississippi and Illinois Waterway. U.S. Army Corps of Engineers, Huntington, West Virginia, 2004.

Davidson, R. and J.G. Mackinnon. Estimation and Inference in Econometrics. Oxford University Press, New York, 1993.

Fellin, L., S. Fuller, W. Grant, and C. Smotek. "Measuring Benefits From Inland Waterway Navigation Improvements.” Journal of the Transportation Research Forum 40(2), (2001): 97-112.

Fruin, J.E., D.W. Halbach, and L.D. Hill. Corn Movements in the United States, Interregional Flow Patterns and Transportation Requirements in 1985. Agricultural Experiment Station, College of Agriculture, University of Illinois at Urbana-Champaign, 1990.

Gervais, J.P., T. Misawa, M.J. McVey, and C.P. Baumel. "Evaluating the Logistic and Economic Impacts of Extending 600-Foot Locks on the Upper Mississippi River: A Linear Programming Approach.” Journal of the Transportation Research Forum 40(4), (2001): 83-104.

Harnish, G. and J. Dunn. "A Short Run Analysis of Grain Barge Rates on the Mississippi River System.” Proceedings of the Transportation Research Forum 40, (1998): 557-572.

Hendrickson, K. and W. Wilson. A Model of Spatial Market Areas and Transportation Demand. U.S. Army Corps of Engineers, Institute of Water Resources. http://www.corpsnets.us/inlandnav. cfm, 2005

Jack Faucett Associates. Waterway Traffic Forecasts for the Upper Mississippi River Basin, Vol. I Summary and Vol. II Grain. http://www.mvr.usace.army.mil/pdw/nav_study/JFAreport.pdf, 1997.

Jack Faucett Associates. Review of Historic and Projected Grain Traffic on the Upper Mississippi River and Illinois Waterway: An Addendum. http://www.mvr.usace.army.mil/pdw/nav_study/ JFAreport.pdf, 2000. 
A Model of Corn and Soybean Shipments

Miljkovic, D., G.K. Price, R.J. Hauser, and K.A. Algozin. "The Barge and Rail Freight Market for Export-Bound Grain Movement from Midwest to Mexican Gulf: An Econometric Analysis.” Transportation Research Part E 36, (2000): 127-137.

Sitchinava, N., W.W. Wilson, and M. Burton. "Heterogenous Products, Demanders and Elasticities.” unpublished manuscript, 2007.

Stock, J.J. and M.W. Watson. Introduction to Econometrics. Addison-Wesley, New York, 2003.

U.S. Army Corps of Engineers. Waterborne Commerce of the United States, Calendar Year 2000, Part 2-Waterways and Harbors, Gulf Coast, Mississippi River and Antilles, p. 68. New Orleans, Louisiana, 2002.

U.S. Army Corps of Engineers. Waterborne Commerce of the United States, Calendar Year 2003, Part 2-Waterways and Harbors, Gulf Coast, Mississippi River and Antilles, p. 63-64. New Orleans, Louisiana, 2005.

U.S. Department of Agriculture, Agricultural Marketing Service. Transportation of U.S. Grains: A Modal Share Analysis, 1978-2000. Washington, D.C., 2004.

U.S. Department of Agriculture, National Agricultural Statistics Service (NASS). Grain Stocks, several January issues. Washington, D.C.

U.S. Department of Agriculture, National Agricultural Statistics Service (NASS). Indiana Agricultural Statistics-Annual Summary 2004-05. Washington, D.C., 2006. http://www nass. usda.gov/in/ind_agstat.html.

U.S. Department of Energy. Energy Information Administration. Petroleum Navigator, 2007. http:// tonto.eia.doe.gov/dnav/pet/hist/a223600002m htm.

U.S. Department of Labor, Bureau of Labor Statistics. Employment Cost Index: Wages and Salaries-Private Industry, Transportation and Public Utility Workers, 2007. http://www.economy. com/freelunch.

Yu, T.H. and S. Fuller. "The Measurement of Grain Barge Demand on Inland Waterways: A Study of the Mississippi River.” Journal of the Transportation Research Forum 44(1), (2005): 27-39.

Yu, T.H., J. Zhang, and S. Fuller. "Freight Transportation Demands on the Upper Mississippi and Illinois Rivers.” Journal of the Transportation Research Forum 45(2), (2006): 119-136.

\section{Acknowledgement}

The authors express their gratitude to Professor Dong Li of Kansas State University, who provided vital assistance in database management and statistical estimation. 
A Model of Corn and Soybean Shipments

Michael W. Babcock is professor of economics at Kansas State University (KSU). In his 34-year career at KSU, he has published over 75 articles in professional journals, along with numerous monographs and technical reports, and his is research has been cited in more than 70 books, the transportation press, and professional journals. He has presented 85 papers at professional meetings, and he was principal investigator or co-investigator on 30 federal and state government research grants worth a total of $\$ 1.92$ million. Babcock is recognized as a leading national and international authority in three research areas including shortline railroad transportation, agricultural transportation, and impact of public policy on transportation market shares.

He has received numerous national awards for his transportation research. He has been recognized five times by the Transportation Research Forum for outstanding research in transportation economics. In addition, Babcock has received the Edgar S. Bagley Award four times from the KSU Department of Economics for outstanding achievement in transportation economics research. In 1999 he was awarded the ISBR Senior Faculty Award for Research Excellence in the Social and Behavioral Sciences from Kansas State University. In 2005 he received the Herbert O. Whitten TRF Service Award for professional contributions to TRF.

Stephen Fuller is a Regents professor in the Department of Agricultural Economics at Texas A\&M University. Fuller's research focuses on agricultural marketing and transportation issues. 
A Model of Corn and Soybean Shipments

APPENDIX A

2SLS Estimates of Grain Barge Demand on the Ohio River (Excluding Exports) (1992-2004)

\begin{tabular}{lcc}
\hline Variable & Coefficient & t-statistic \\
\hline ORSHIP $_{\mathrm{t}-1}$ & 0.394 & $5.72^{* * *}$ \\
ORRATES $_{\mathrm{i}}$ & $1,884.9$ & $4.63^{* * *}$ \\
CBStock $_{\mathrm{i}}$ & 0.347 & $5.77^{* * *}$ \\
ORJP $_{\mathrm{i}}$ & $-3,233.4$ & $-2.07 * *$ \\
INCP $_{\mathrm{i}}$ & 465.9 & 0.51 \\
Constant $_{\text {Adjusted R }}^{2}$ & $-158,096.7$ & -1.30 \\
\hline
\end{tabular}

* significant at the .10 level

$* *$ significant at the .05 level

*** significant at the .01 level

\section{APPENDIX B}

2SLS Estimates of Grain Barge Demand on the Ohio River (Excluding Grain Stocks)

\begin{tabular}{lcc} 
& \multicolumn{2}{c}{$(1992-2004)$} \\
Variable & Coefficient & t-statistic \\
\hline ORSHIP $_{\mathrm{t}-1}$ & 0.548 & $8.17^{* * * *}$ \\
ORRATES $_{\mathrm{i}}$ & $1,127.6$ & $1.96^{*}$ \\
EXPORT $_{\mathrm{i}}$ & 73.2 & $3.27^{* * *}$ \\
ORJP $_{\mathrm{i}}$ & $-1,713.4$ & -0.99 \\
INCP $_{\mathrm{i}}$ & -383.0 & -0.40 \\
Constant $_{\text {Adjusted R }}^{2}$ & $-195,783$ & -1.57 \\
\hline
\end{tabular}

* significant at the .10 level

** significant at the .05 level

*** significant at the .01 level 